\title{
CONVULSÃO DAS SOMBRAS
}

\section{SHADOWS CONVULSION}

\section{Eugénia Vilela ${ }^{1}$}

Alik Wunder ${ }^{2}$

O que acontece quando o enquadramento são os fragmentos de imagens, fotografias em lentidão de luz que envolve o branco?

O que pensar quando o sentido é o avesso das formas reconhecíveis?

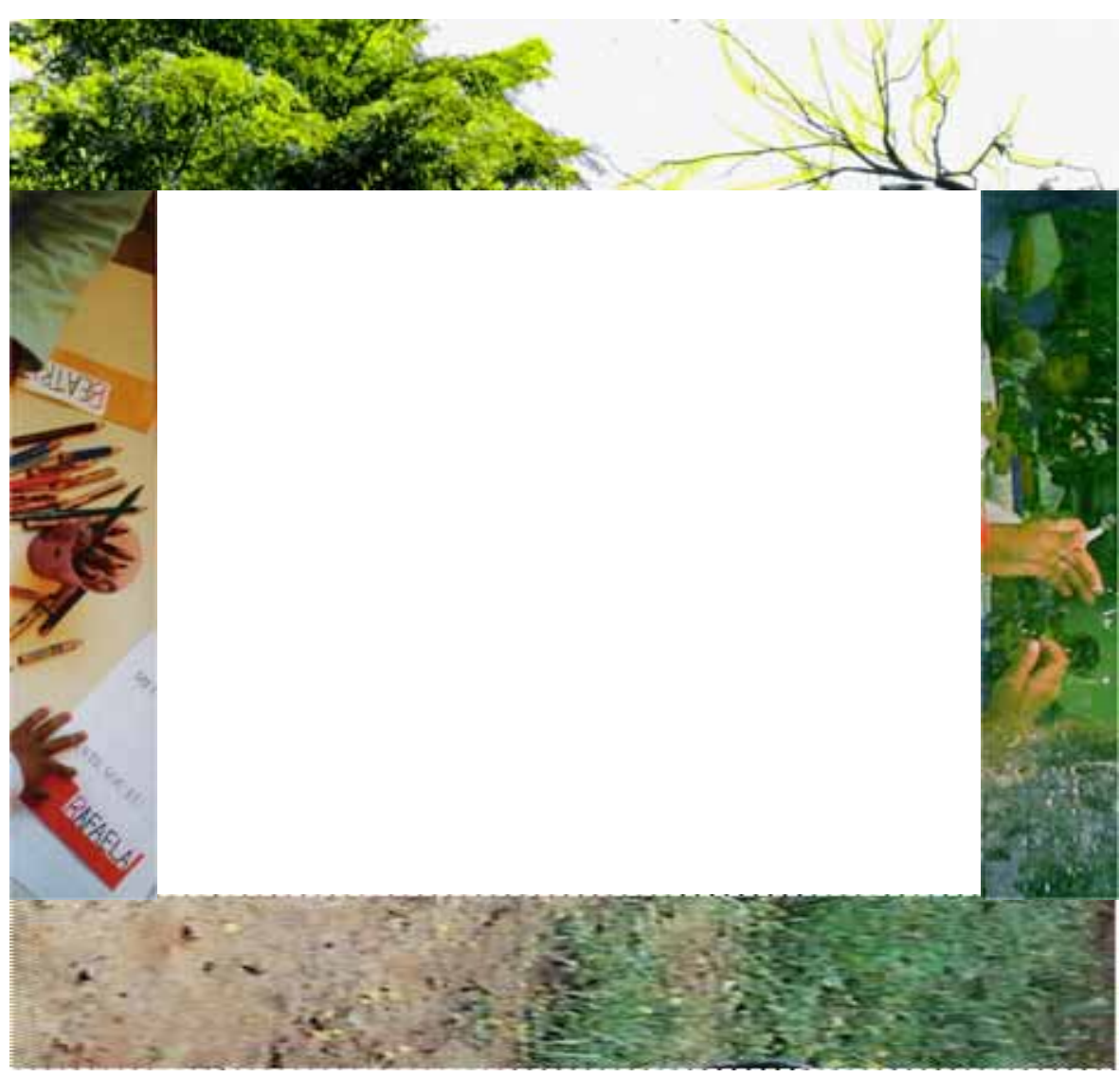

${ }^{1}$ Fragmentos da argüição da Banca de Defesa de Doutoramento de Alik Wunder. (Texto)

${ }^{2}$ Montagens criadas a partir de fotografias de educadoras que compõe o capítulo Pensamento por imagens, imagens por pensamentos da Tese de Doutorado: "Foto quase grafia, o acontecimento por fotografias de escolas”, defendida na Faculdade de Educação - Unicamp em 2008. (Composições de imagens). 
O instante decisivo de uma fotografia possui o fulgor de um momento onde uma porção de luz se prende a um gesto que toca a verdade desse momento como uma errância no silêncio.

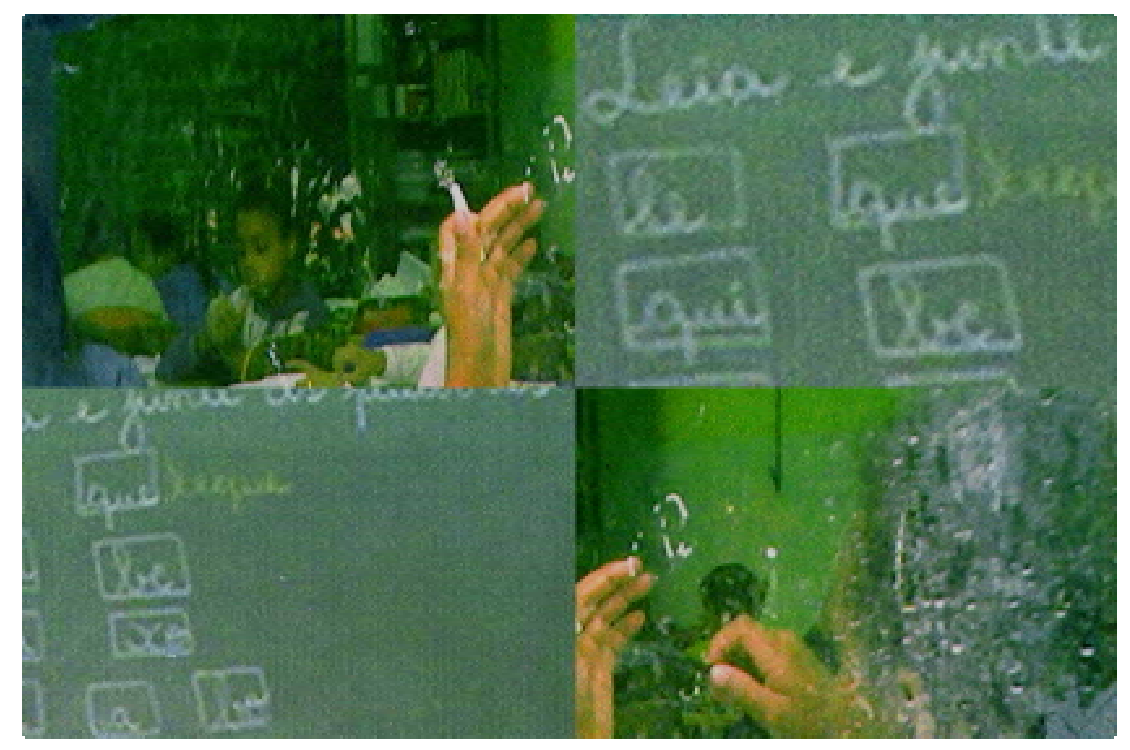

Verde o quadro onde se desprendem as palavras. $O$ vidro onde se dobram as mãos num movimento do giz, da superfície do traço, da mão, do vidro da lousa, da imagem; superfícies em antecipação, indícios. 
As imagens escolares surgem como fragmentos de uma história. Mas surge a interrogação: "como restituir principialidade às imagens?” Talvez pela força dos fragmentos que a constituem. Redescobrir a força do iniciar no seio destes fragmentos.

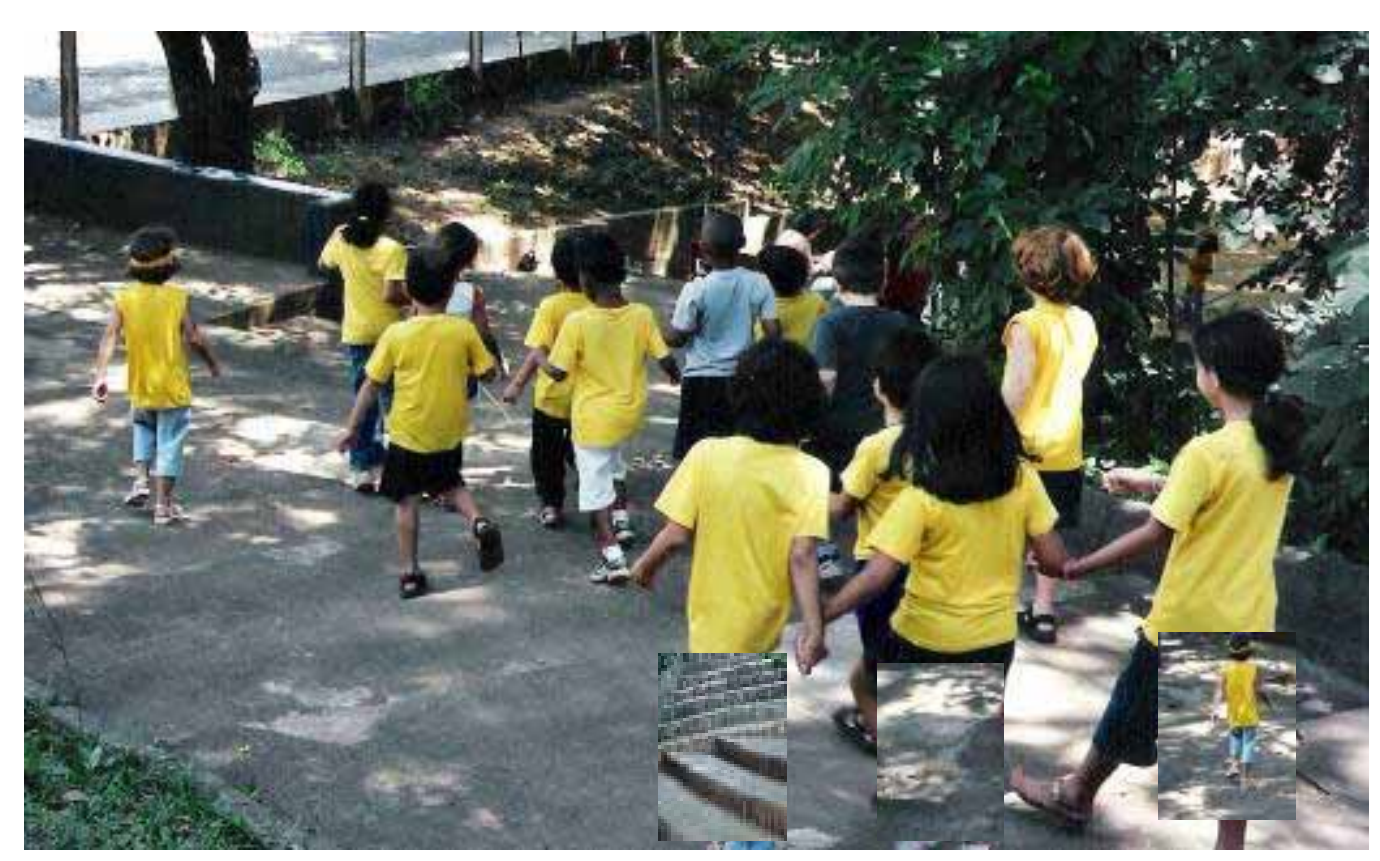




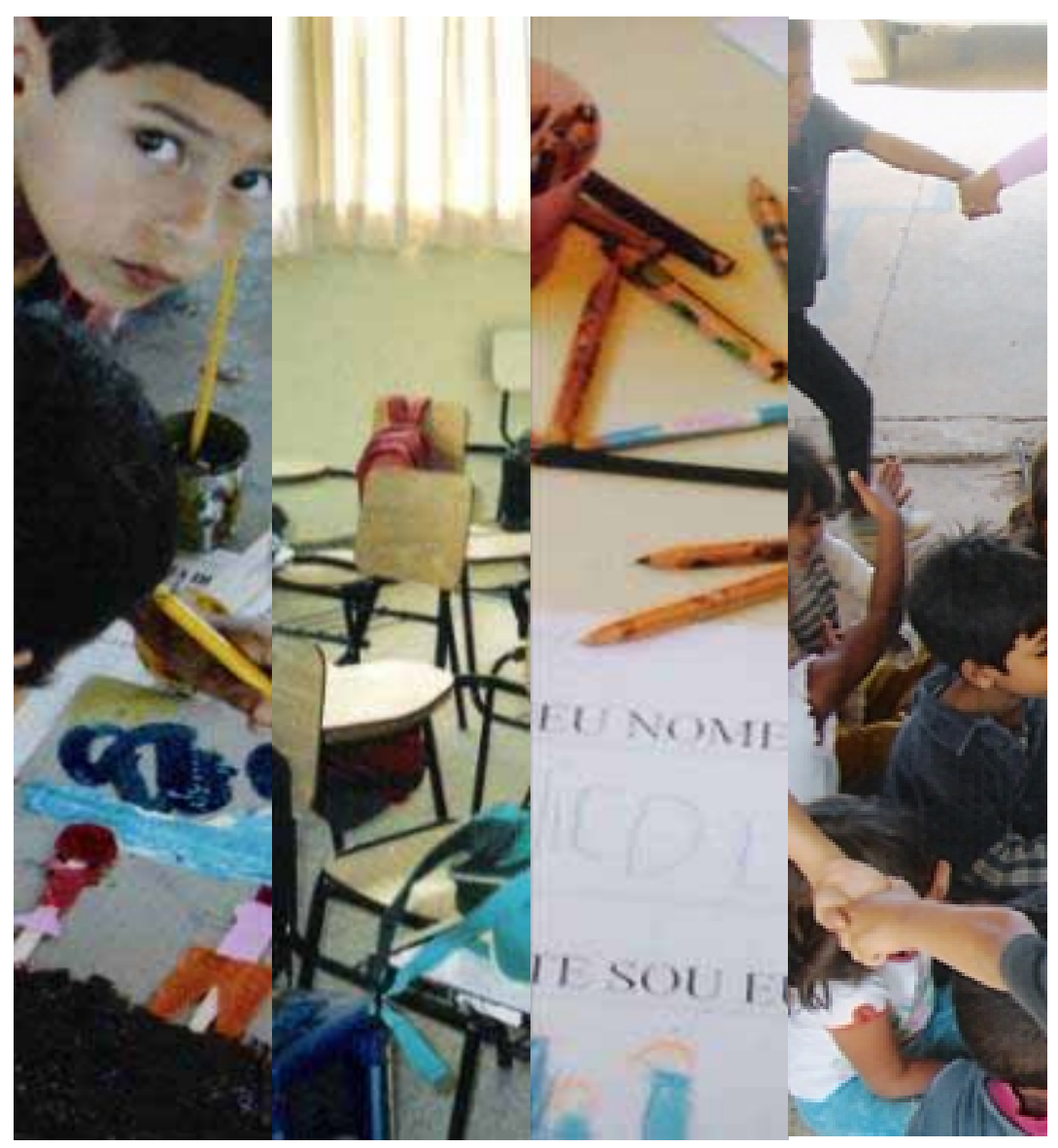

Um corpo-criança sempre presente, um riso que nos convida para dentro da roda, uma sala vazia, os objectos que indiciam traços, presenças imperfeitas no interior de uma sala onde a janela aberta permitiu a ausência. Numa folha de papel branca estão escritos “Meu nome”/“este sou eu”; crianças pintam as cores que convocam o nosso olhar para dentro, contudo o ponto de fuga de todas elas é esse gesto de uma criança que levanta o seu olhar singular e conduz o espaço directamente para o fora de campo; aquele que olha, é olhado por aquele que é evidência. A evidência é quebrada pelo olhar de uma criança que nos lança para fora do eixo de um mundo. 
O movimento de uma criança em suspensão, o instante imediatamente antes do gol.

O corpo eternamente suspenso, sustentável leveza de um corpo em desequilíbrio.

A que lugar corresponde o real na sombra do chão que indicia um outro corpo, um outro movimento?

No recorte da imagem,

apenas as sombras

e toda a imagem se torna mais nítida. A nitidez do mundo irrompe nas sombras e inverte a nitidez evidencial da imagem anterior: a imagem a que o recorte da sombra se equivale.

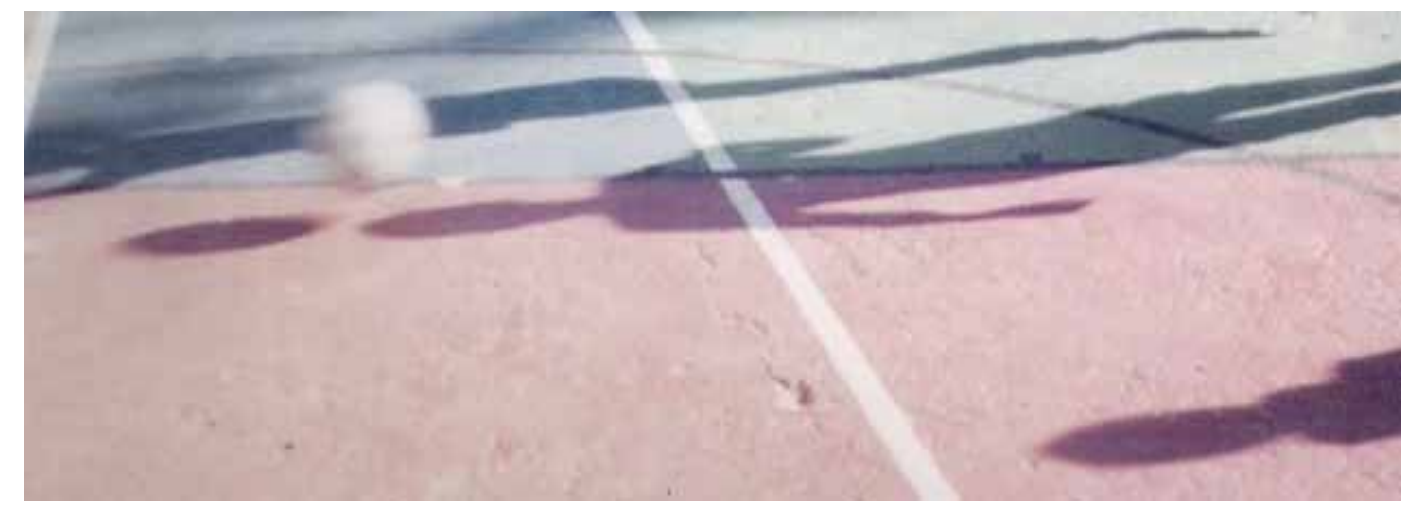



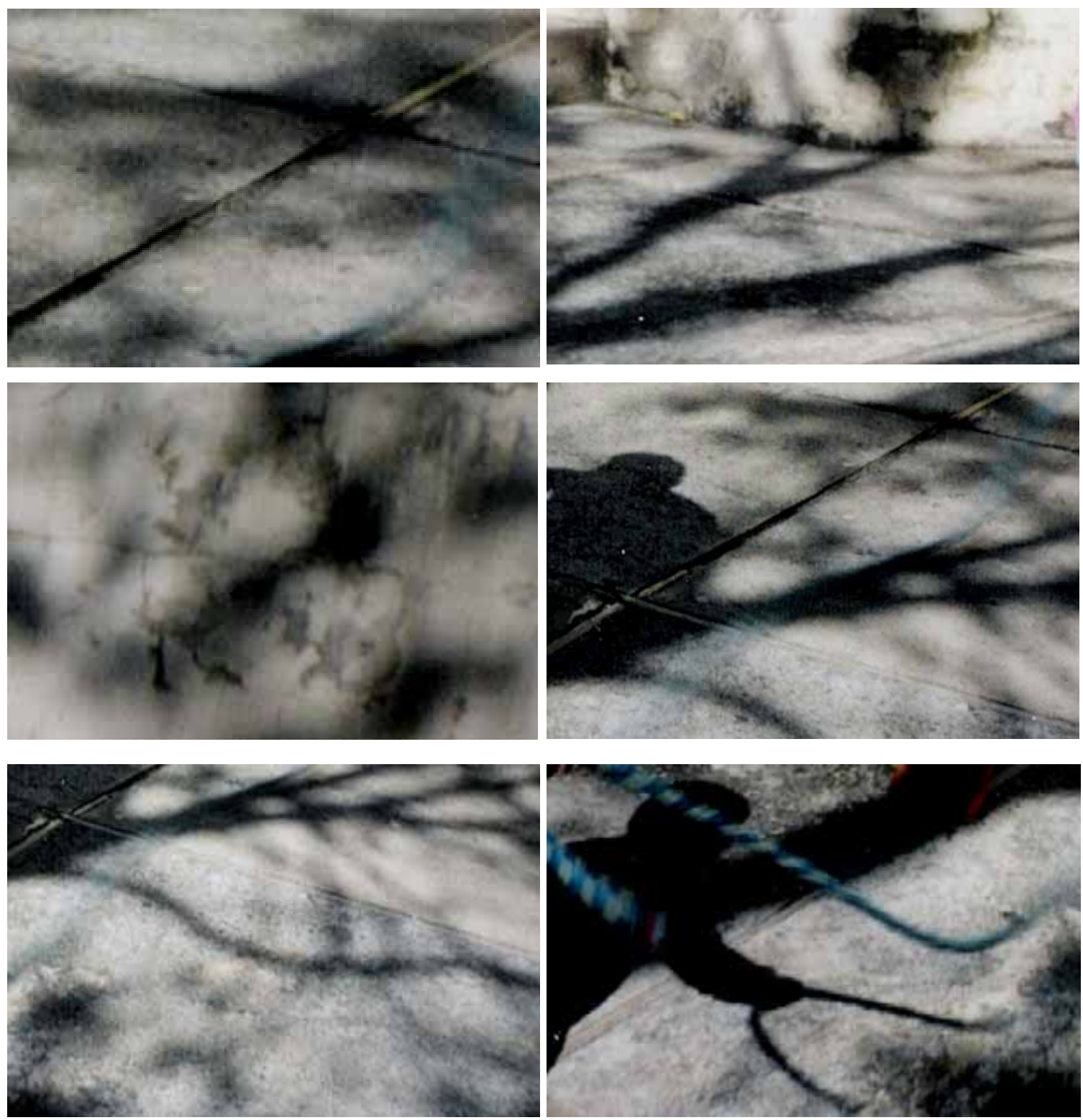

Um instante

simultaneamente frágil e decisivo. As fotografias resistem a um dizer último com seus silêncios, criam uma sombra dissidente de uma imagem definitiva (Vilela, 2006), do tempo, das coisas, dos seres... Uma turbulência visível. Há mesmo uma criançasombra que não nos oferece outra coisa do que a sua potência de não-aparecer. 
Lilazes imprecisos.

Revelação de um

traço no nome das

cores em alucinação

na água.
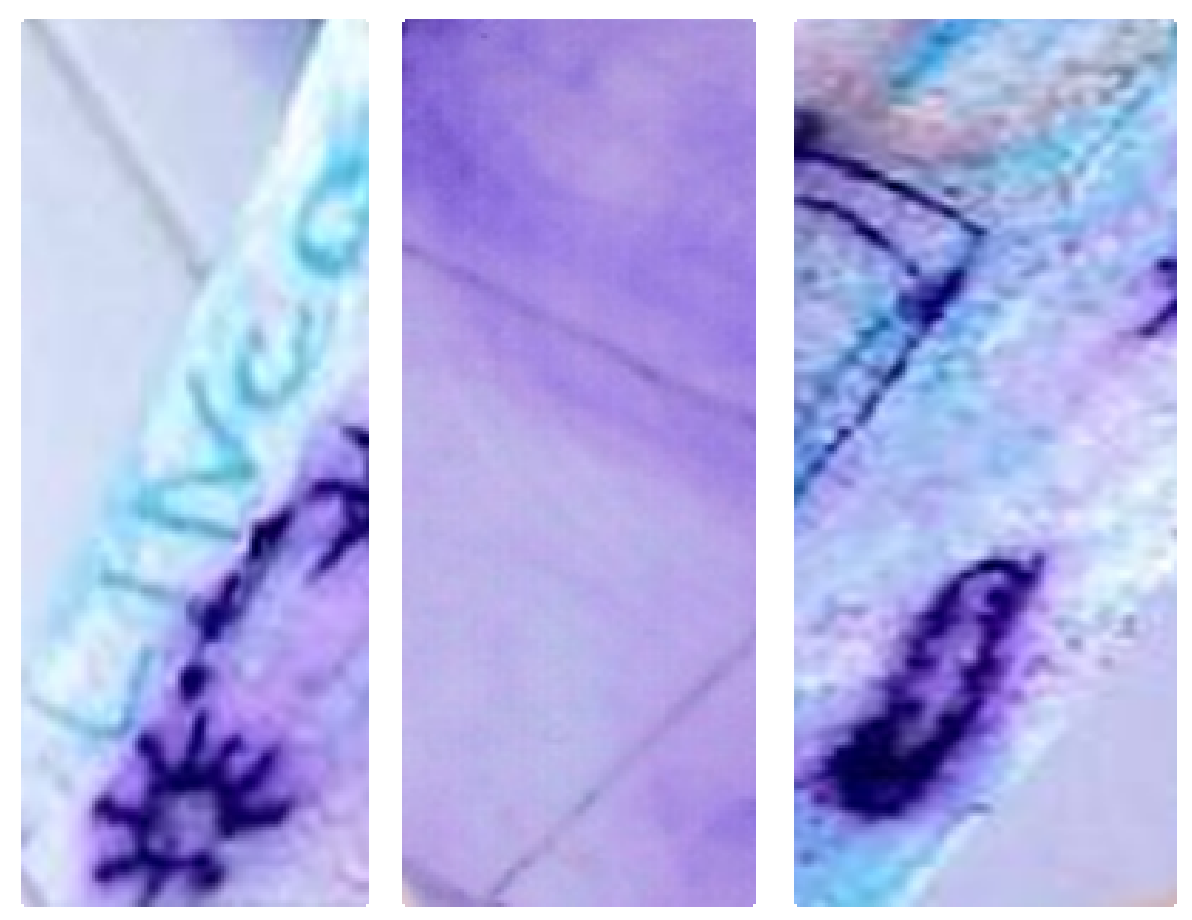

(c) ETD - Educação Temática Digital, Campinas, v.9, n. esp., p.266-277, out. 2008 - ISSN: 1676-2592 


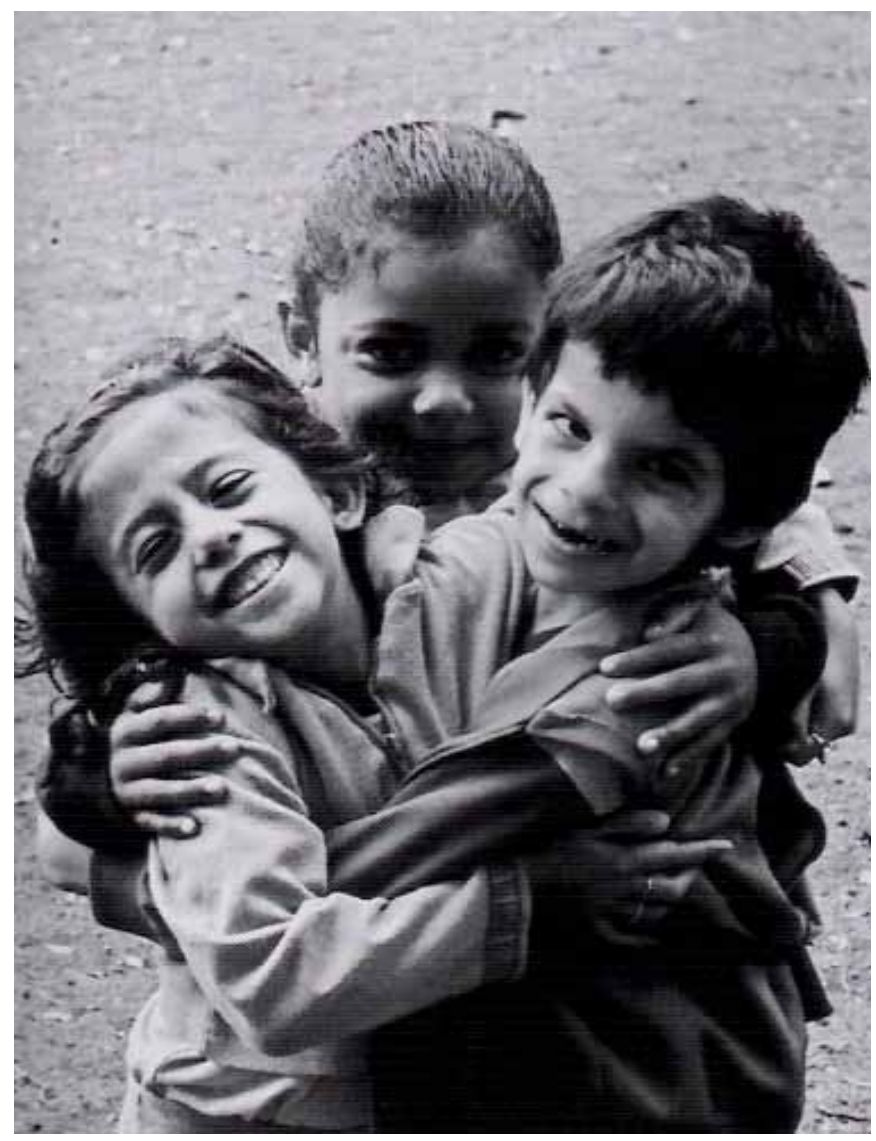

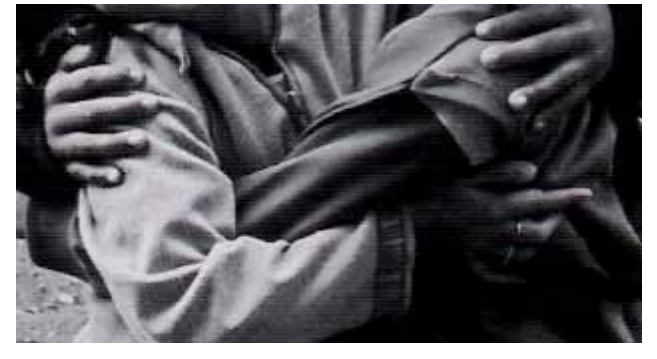
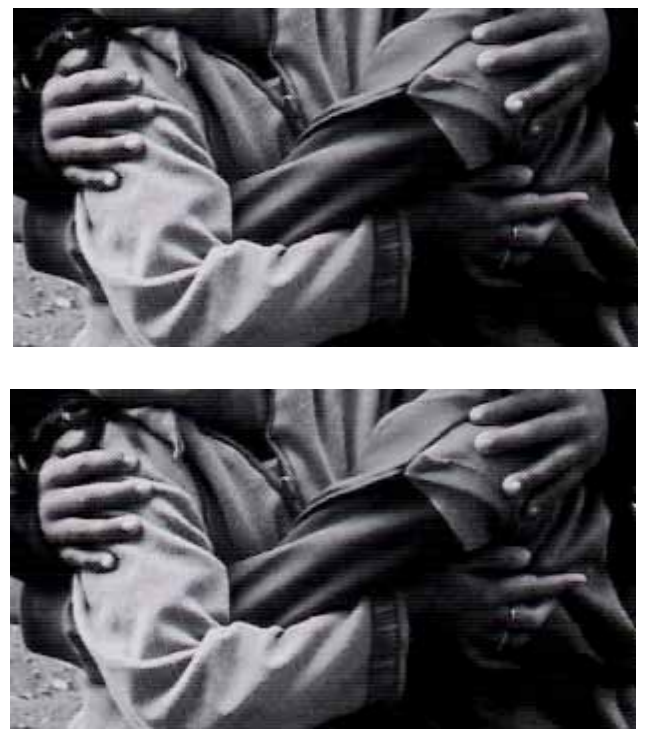

As fotografias são objectos únicos e concretos que fixam a singularidade de um momento. Se, por um lado, marcam - numa escrita de luz - um texto no corpo do mundo, (ao qual

regressaremos indefinidamente), por outro lado fazem-nos tocar um acontecimento - o silêncio de um olhar onde os nomes se declinam no corpo. 


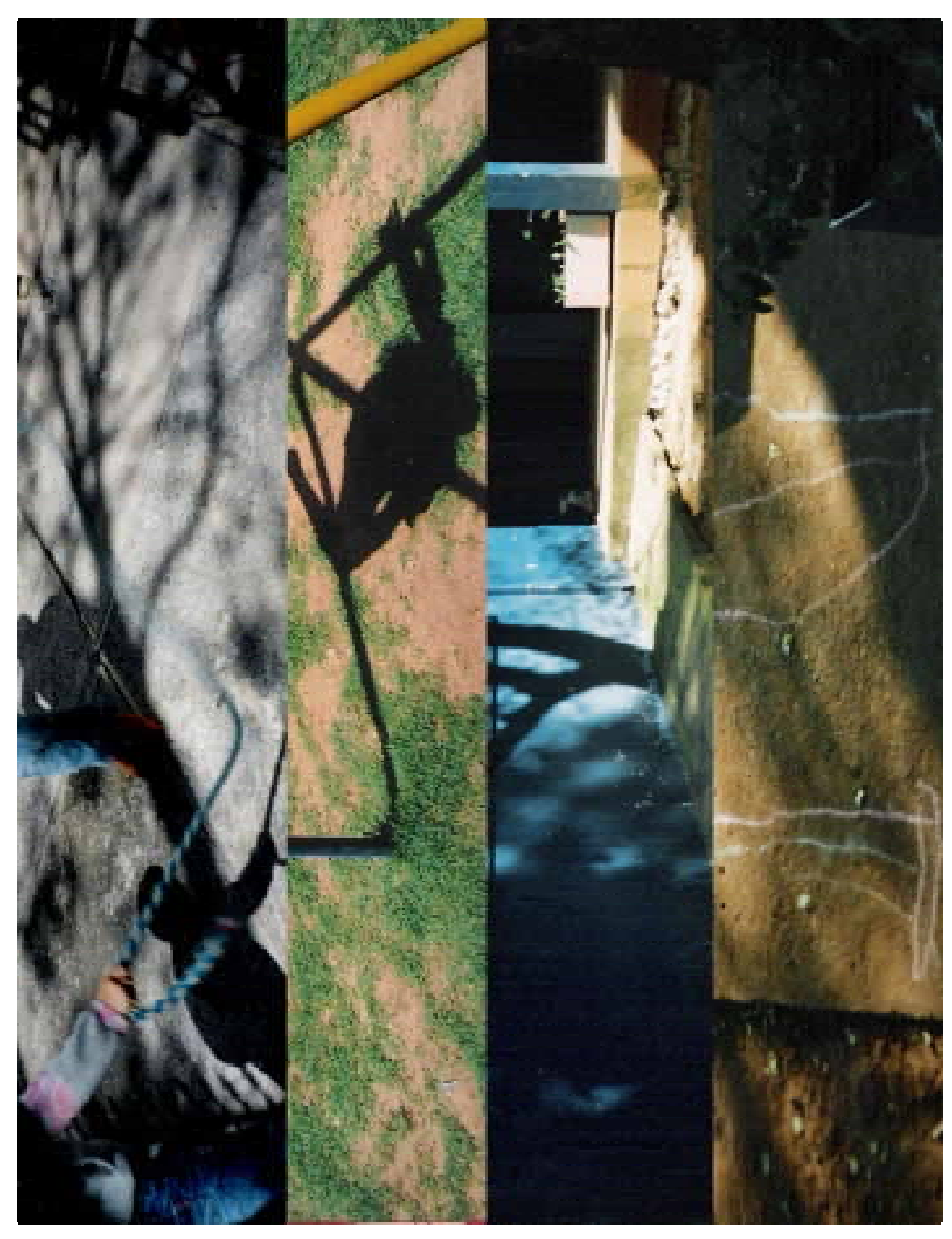

Lâminas das sombras e das linhas, árvore, corda, corpo, balanço, giz, outra história, primeiro o que virá, depois só depois o que passou.

Convulsão dos tempos. 
Pela beleza dos fragmentos de tempos coagulados (Vilela, 2007) nas fotografias procura-se - do instante ordinário ao tempo indeterminado - um dizer em fulguração (Wunder, 2008).

Na dobra da força-marca, a força-ferida abre um tempo em devir (Wunder, 2008). E nesta fissura poética, as fotografias surgem como peles justapostas em repetidas composições, cortes, passagens, recomposições.

Sombra-pele-criança-linguagem-corposilêncio: uma única ferida no corpo das palavras sem destino.

Errância no ângulo da raiz calcinada do sentido.

O mundo ali tinha de ser de se recomeçar. (Guimarães Rosa, Grande Sertão: Veredas, p.474). 


\section{REFERÊNCIAS}

VILELA, E. Resistência e acontecimento. As palavras sem centro. In: KOHAN, W. O. Foucault 80 anos. Belo Horizonte: Autêntica, 2006, p.107-128.

2007

Silêncios Tangíveis. Corpo, resistência e testemunho nos espaços contemporâneos de abandono. Porto. Edições Afrontamento,

WUNDER, A. Foto quase grafias, o acontecimento por fotografias de escolas. 2008. 127 fl.Tese (Doutorado) - Faculdade de Educação, Universidade Estadual de Campinas, Campinas, 2008. 


\section{Crédito das imagens:}

página 266: montagem a partir das fotografias de Gene Heber, Rosimar Alves, Janayna Fernandes Pinheiro, Silvana Lessio. página 267: montagem a partir de recorte de fotografias de Gene Heber.

página 268: montagem a partir da fotografia de Adélia Fernanda Pereira Araújo.

página 269: montagem a partir das fotografias de Anna Paula Silva , Lídice Ferreira, Janayna Pinheiro.

página 270: recorte de fotografia de Edilene Venute Miranda.

página 271: montagens a partir da fotografia de Alessandra Venâncio.

página 272: montagem a partir da fotografia de Sidnéia Oliveira dos Santos.

página 273: montagem a partir de fotografia de Regina Arcuri Santomauro.

página 274: montagem a partir das fotografias de Alessandra Venâncio, Janayna Pinheiro, e Márcia de Jesus dos

Santos Ferreira Toma.

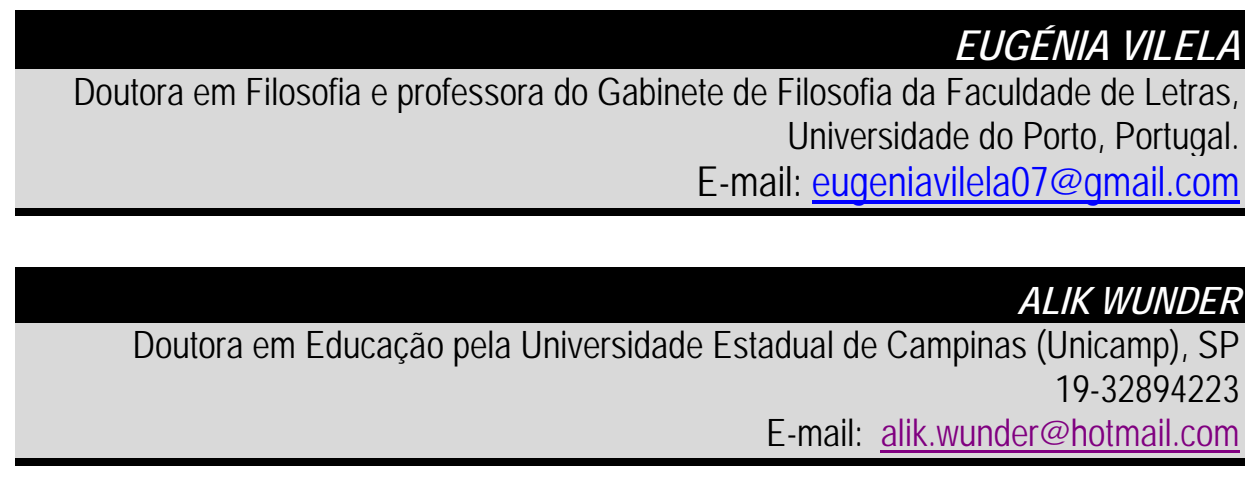

Recebido em: 10/03/2008

Publicado em: 20/10/2008 